ФЕЛЬДМАН Павел Яковлевич - кандидат политических наук, доцент; доцент кафедры философии и социологии Академии труда и социальных отношений (119454, Россия, г. Москва, ул. Лобачевского, 90); заместитель директора Института стратегических исследований и прогнозов Российского университета дружбы народов (117198, Россия, г. Москва, ул. Миклухо-Маклая, 6, комн.311; pavelfeld@gmail.com)

\title{
ПРОФЕССИОНАЛЬНЫЕ СОЮЗЫ В СИСТЕМЕ ОБЩЕСТВЕННОГО КОНТРОЛЯ ЗА РЕАЛИЗАЦИЕЙ МАЙСКИХ УКАЗОВ ПРЕЗИДЕНТА РФ
}

Аннотация. В статье оцениваются перспективы интенсификации общественного контроля за реализацией майских указов Президента РФ в части повышения уровня заработной платы граждан. Автор приходит к выводу, что в российском социуме назрел запрос на транспарентный, публичный и объективный мониторинг социально-трудовой сферы со стороны профессиональных союзов. Результаты подобного мониторинга играли бы не менее важную роль, чем данные официальных органов государственной статистики.

Ключевые слова: общественный контроль, профессиональные союзы, майские указы, гражданское общество, российская политика

$\mathrm{O}^{6}$ беспечение ускоренного социально-экономического развития России требует консолидированных усилий со стороны государства и гражданского общества. Несмотря на сокращение доходов от экспорта углеводородов и введение западных санкций в отношении нашей страны, с правительства не снимаются обязательства по выполнению майских указов В.В. Путина в части повышения уровня оплаты труда работников бюджетной сферы. Так, к концу 2018 г. предполагалось полностью претворить в жизнь наиболее принципиальные положения указа № 597 «О мероприятиях по реализации государственной социальной политики», предписывающего существенным образом увеличить заработную плату учителям, врачам, преподавателям вузов, научным сотрудникам и представителям других профессиональных групп. Очевидно, что деятельность федеральных и региональных органов исполнительной власти, ответственных за выполнение данной задачи, в силу объективных причин нуждается в эффективном общественном контроле.

К началу 2019 г. подведение итогов реализации «зарплатного» компонента майских указов семилетней давности представляется достаточно сложной задачей. С одной стороны, правительство отчиталось перед главой государства об их всеобъемлющем выполнении, а с другой - сами граждане на местах выражают скепсис по поводу соответствия уровня оплаты их труда целевым показателям. Общероссийский народный фронт, принявший на себя роль центрального института демократического контроля за реализацией президентских инициатив, так и не предъявил широкой аудитории комплексные результаты соответствующего мониторинга. В данных условиях закономерно было ожидать наиболее внятной реакции от организаций, специализирующихся на изучении социально-трудовой сферы и обладающих доступом к реальным трудовым коллективам, - профессиональных союзов.

На сегодняшний день в России функционирует целый ряд автономных профцентров. По сложившейся научной традиции их принято подразделять на «традиционные» (входящие в состав ФНПР) и «альтернативные»- менее крупные ассоциации, позиционирующие себя как «подлинно независимые» от государства 
(на практике эта пресловутая «независимость» вызывает определенные сомнения). Профсоюзы традиционного типа придерживаются относительно мягкой политики согласования корпоративных интересов, участвуя в работе территориальных и отраслевых трехсторонних комиссий. «Альтернативные» объединения наемных работников («Соцпроф», «Учитель», «Действие», «Университетская солидарность», «Конфедерация труда России» и др.), находясь за рамками официальных институтов социального партнерства, демонстрируют более высокую активность в медийном пространстве и периодически организуют коллективные действия протестного характера, однако отождествлять их с оппозиционными структурами было бы не вполне корректно.

С большой долей вероятности можно утверждать, что их подключение к мониторингу выполнения майских указов 2012 г. способствовало бы укреплению имиджа профсоюзного движения России. Во-первых, подобная деятельность привлекает внимание широкой общественности и средств массовой информации; во-вторых, она интегрирует наемных работников в процесс реализации демократического контроля; в-третьих, повышает авторитет тред-юнионов перед лицом работодателей, государства и людей труда. В той или иной степени проблемой майских указов занимались все профсоюзные организации, объединяющие так называемых бюджетников (прежде всего, учителей, врачей и научно-педагогических работников). Однако контент-анализ электронных и печатных изданий позволяет констатировать, что «традиционные» профсоюзы выступали с публичным оглашением результатов соответствующего мониторинга крайне редко. Так, в сфере образования основным поставщиком комментариев о ходе выполнения майских указов стал профсоюз «Учитель» (более 60\% публикаций в прессе). Остальные $40 \%$ материалов приходятся на упоминания региональных организаций профсоюза работников народного образования и науки РФ в местных СМИ. Аналогичным образом «традиционный» профессиональный союз работников здравоохранения РФ существенно уступил в медийной активности недавно созданному «Альянсу врачей» и объединению медработников «Действие».

Вышеуказанное обстоятельство невозможно объяснить исключительно пассивностью профсоюзов традиционного типа. Очевидно, что, желая сохранить за собой привилегированное положение в системе социального партнерства, они не могли включиться в процесс всеобъемлющего и публичного мониторинга выполнения майских указов без четкого сигнала со стороны государства. Вероятно, объективные результаты подобного мониторинга способны вызвать масштабный общественный резонанс в случае их обнародования. Как минимум они могут серьезно отличаться от официальных данных Росстата и правительства РФ. В этой связи заслуживает внимания инициатива министра экономического развития М.С. Орешкина по созданию в России системы общественного контроля над процессом сбора государственной статистики. Аналогичная мысль прозвучала в Послании Президента РФ Федеральному Собранию 2019 г., когда В.В. Путин предложил подвести первые итоги работы по национальным проектам на основе оценок самих граждан ${ }^{1}$. Дабы следовать этому тренду, профсоюзам необходимо выстроить собственную систему агрегирования информации, поступающей от низовых трудовых коллективов на федеральный уровень. Результаты настоящего мониторинга следует сделать достоянием СМИ и широкой общественности. Внедрение подобной практики, вероятно, будет осложнено неизбежным давлением на тред-юнионы со стороны руководителей

1 Послание Президента РФ Федеральному Собранию 2019 г. Доступ: http://kremlin.ru/events/ president/news/59863 (проверено 21.02.2019). 
бюджетных организаций и региональных властей. Наибольшие затруднения при этом испытают профсоюзы традиционного типа, избегающие конфликтогенных факторов в отношениях с государством и работодателями. Таким образом, мандат на реализацию подобного проекта в масштабах страны может быть дан исключительно президентом РФ, авторитет которого способен оградить объединения наемных работников от административного давления на местах.

Помимо волевого участия главы государства, для построения системы профсоюзного контроля за выполнением майских указов важную роль будет играть активность самих граждан. Существуют определенные опасения, что «глубинный народ» (термин взят из резонансной статьи В.Ю. Суркова в «Независимой газете») проигнорирует это начинание ${ }^{1}$. Иными словами, важно установить наличие или отсутствие общественного запроса на такого рода мониторинг. О его потенциально высокой социальной востребованности косвенно свидетельствует «вирусная» популярность так называемого профсоюза Навального в сети Интернет. С правовой точки зрения данная структура не имеет ничего общего с профсоюзным движением, поскольку не предполагает наличия первичных организаций и действует за рамками Трудового кодекса РФ. Основная идея проекта заключается в том, чтобы работники бюджетной сферы узнавали, насколько их заработная плата отличается от целевых показателей, зафиксированных в майских указах, и массово обращались в контрольно-надзорные органы с жалобами.

Алгоритм работы профсоюза Навального построен на целенаправленно искаженном, манипулятивном подходе к интерпретации президентских инициатив. Тем не менее упомянутый представитель несистемной оппозиции в считанные дни стал едва ли не самой заметной фигурой на ниве профсоюзного мониторинга социально-трудовой сферы. Что характерно, пресс-секретарь главы государства Д.С. Песков прокомментировал очередное начинание А.А. Навального фразой: «...любое участие в контроле за “майскими указами” востребовано»². И все же развернутая в Интернете кампания с высокой долей вероятности являет собой пример не столько общественного контроля, сколько протестной мобилизации граждан. Впрочем, не исключено, что она приведет к выявлению локальных нарушений и злоупотреблений на местах. Спровоцированный ею общественный резонанс говорит о необходимости построения цивилизованной системы демократического контроля за выполнением майских указов, ключевым институциональным звеном которой должны стать не политические оппозиционеры, а профессиональные союзы, сосредоточенные на правозащитной деятельности.

\footnotetext{
1 Владислав Сурков: Долгое государство Путина. - Независимая газета. 11.02.2019. Доступ: http:// www.ng.ru/ideas/2019-02-11/5_7503_surkov.html (проверено 21.02.2019).

2 В Кремле ответили на планы Навального следить за исполнением «майских указов». Доступ: https://www.interfax.ru/russia/647700 (проверено 21.02.2019).
} 
FEL'DMAN Pavel Yakovlevich, Cand.Sci. (Pol.Sci.), Associate Professor; Associate Professor of the Chair of Philosophy and Sociology, Academy of Labor and Social Relations (90 Lobachevskogo St, Moscow, Russia, 119454); Deputy Director of the Institute of Strategic Studies and Predictions, Peoples' Friendship University of Russia (app. 311, 6 MiklukhoMaklaya St, Moscow, Russia, 117198; pavelfeld@gmail.com)

\section{TRADE UNIONS IN THE SYSTEM OF PUBLIC CONTROL OVER THE IMPLEMENTATION OF THE MAY DECREES OF THE PRESIDENT OF THE RUSSIAN FEDERATION}

Abstract. The article assesses the prospects for the intensification of public control over the implementation of the May decrees of the President of the Russian Federation in terms of increasing the level of wages of citizens. The author concludes that in Russian society brews the request for a transparent, public and objective monitoring of the social and labor sphere by the trade unions. The results of such monitoring will be no less important than the data of official state statistics bodies. Keywords: public control, trade unions, May decrees, civil society, Russian politics

БЕЛОКОНЕВ Сергей Юрьевич - кандидат политических наук, доцент; руководитель департамента политологии и массовых коммуникаций Финансового университета при Правительстве РФ (125993, Россия, г. Москва, ГСП-3, Ленинградский пр-кт, 49; pr-rsuh@yandex.ru)

УСМАНОВА Заира Романовна - кандидат политических наук, доцент департамента политологии и массовых коммуникаций Финансового университета при Правительстве РФ (125993, Россия, г. Москва, ГСП-3, Ленинградский пр-кт, 49; rassol2007@yandex.ru)

\section{ПЕРСПЕКТИВЫ ТРУДОВОЙ МИГРАЦИИ ИЗ РАЗВИВАЮЩИХСЯ СТРАН В РОССИЮ: СОЦИОКУЛЬТУРНЫЙ И ПОЛИТИКО- ЭКОНОМИЧЕСКИЙ АСПЕКТЫ}

Аннотация. В статье предлагается обзор моделей решения ряда проблем, связанных со спецификой глобальной международной миграции в XXI в. Авторы анализируют прогностический потенциал современных научных подходов к указанной проблематике, проводят компаративный анализ сценариев решения миграционных проблем в результате кризиса в Европе. В отдельный исследовательский блок вынесен обзор механизмов государственной регуляции миграционных процессов, применяемых в европейских странах, и возможности экстраполирования этих методов на российскую специфику. В качестве вариативного кейса рассмотрен пример привлечения в Россию мигрантов-христиан из стран Африки. Авторы предлагают ряд мер по правовому сопровождению, социокультурной и политико-экономической адаптации мигрантов, а также предупреждению противоправного и деструктивного поведения мигрантов - носителей комплиментарной и конфликтогенной моделей социальной идентичности.

Ключевые слова: миграция, миграционные процессы, трудовая миграция, миграционная политика, принимающее сообщество, социокультурная и политико-экономическая интеграция, миграционные риски, социальная идентичность

$\mathrm{M}$ играционные процессы - неизбежный и объективно важный продукт развития мировой цивилизации, специфика которого подвержена значительной трансформации при стремительно развивающихся общественных отношениях в условиях глобализации в ближайшей исторической перспективе. Для стран-реципиентов в этой связи открывается целый ряд направлений, тре- 